\title{
衝撃波作用による微小気泡群の崩壊と衝撃圧生成*
}

\author{
阿部 晃 久*1, 大谷清 伸*2, 高山和 喜*3 \\ 西尾茂*1, 三村治夫*4, 武田 実*4
}

\section{Pressure Generation from Micro-Bubble Collapse at Shock Wave Loading}

\author{
Akihisa $\mathrm{ABE}^{* 5}$, Kiyonobu OHTANI, Kazuyoshi TAKAYAMA, \\ Shigeru NISHIO, Haruo MIMURA and Minoru TAKEDA \\ ${ }^{* 5}$ Graduate School of Maritime Sciences, Kobe University, \\ 5-1-1 Fukaeminami-machi, Higashinada-ku, Kobe-shi, Hyogo, 658-0022 Japan
}

\begin{abstract}
To explore a reliable technology possibly applicable to the inactivation of micro-creatures in ship ballast water, this paper reports a result of a primary experimental and analytical study. We obtained $10 \mu \mathrm{m}$ bubbles in averaged diameter by using a swirling flow type micro-bubble generator. We exposed a shock wave generated by a micro-explosion of a $10 \mathrm{mg}$ silver azide pellet to the water containing micro-bubbles filled in a $10 \mathrm{~mm}$ wide parallel test section. Observations were carried out with a high-speed camera, and the corresponding rebound pressures of bubbles were measured with a fiber optic probe pressure transducer. We confirmed micro-bubble motion with higher temporal resolution and found that micro-bubble collapse arose in several hundred nano-seconds after the shock loading. The peak pressure generated by bubble collapse was over $200 \mathrm{MPa}$ at the distance of $20 \mathrm{~mm}$ from the explosion center. These experimental results were consistent with those analyzed on the basis of the measured pressure data. The presence of such high impulsive pressures upon bubble collapse clearly indicated that the rebound pressure would be effectively applicable to the inactivation of micro-creatures in ship ballast water.
\end{abstract}

Key Words: Micro-Bubble, Shock Wave, Flow Visualization, Compressible Flow, Gas-Liquid Two-Phase Flow, Rebound Pressure, Pressure Measurement, Ship Ballast Water

\section{1.はじめ に}

近年，海事科学の分野では，船舶の安定制御に不可 欠なバラスト水が, 海洋微生物の越境移動を招き, 海 洋生態系破壊をもたらしているとして，国際的に問題 視されている ${ }^{(1) \sim(3)}$. 国際海事機関（IMO）は， 2004 年に船舶バラスト水の水質に厳しい基準を設定し，船 船排水量に対応した段階的な条約の実施を進め, 各国 に条約の順守を求めている(4)，そのため，世界各国で は，IMO 基準を満たす様々なバラスト水処理システ ムを提案・開発している，主な処理方法として，光触 媒殺菌, キャビテーション作用と脱酸素殺菌の併用, キャビテーション作用とオゾン殺菌の併用, 電磁力に よる菌体の吸着除去などが挙げられる(5)(6).これらに

* 原稿受付 2008 年 9 月 26 日.

*1 正員, 神戸大学海事科学研究科( 业 658-0022 神戸市東灘区 深江南町 5-1-1).

*2 正員, 東北大学流体科学研究所 - 衝擊波学際応用研究部門 (亟980-8577 仙台市青葉区片平 2-1-1).

*3 正員, 名誉員, 東北大学流体科学研究所 - 衝撃波学際応用研 究部門.

*4 神戸大学海事科学研究科.

E-mail : a-abe@maritime.kobe-u.ac.jp
は，すでに IMO 承認を得たものや，航海実験段階の ものがあるが, 導入経費や維持管理費などの経済性, 化学物質使用による環境污染など, 未だ改善すべき課 題を多く残している.

著者らは，バラスト水中の細菌処理に適する安全な 技術開発を目指し, 衝撃压を利用する処理方法を提案 している(7) (8). 先の研究では, アルミニウム容器で封 入した海洋ビブリオ属細菌浮游溶液に, ガス銃で 200 MPa 超の衝撃圧を作用させた結果, 細菌の完全な不活 性化を確認し, その殺菌効果には, 純粋な衝撃压作用 だけでなく，フリーラジカルによる化学作用の寄与が 示唆された ${ }^{(9)}(11)$. 現在, 著者らは, 水中衝撃圧作用 による菌体不活性化を大量のバラスト水処理へ利用す るために, 気泡崩壊時に発生する衝撃圧に着目し，そ の応用可能性を検討している(12). 特に, 微小気泡は, 水中に長時間残存する性質を有するだけでなく，自然 圧壊でフリーラジカルを生成するとの報告 ${ }^{(13)(14)} あ あ$ ることから, 微小気泡の崩壊をバラスト水処理に援用 
することは有効であると考えられる。しかし，微小気 泡の性質は未だ十分解明されておらず，現存の殺菌装 置では，オゾン，二酸化炭素，窒素など，気体の毒性 や脱酸素効果による方法が主であり, 微小気泡の運動 や特性を主に利用した方法はない.

本研究では，微小空気泡生成直後や外圧作用を受け た気泡の挙動観察, 再膨張時に発生する衝撃圧の定量 的評価のため, 可視化と圧力計測を実施し，また，一 次元的ではあるが気泡運動の解析を行った。これらの 結果から, 外圧負荷による微小気泡群の収縮・膨張運 動で菌体不活性化効果を発現できる高い再澎張圧を誘 起できることを確認し，バラスト水処理への応用につ いて検討した。

\section{2. 微小 気 泡}

2.1 発生方法と特徵 実験では，旋回流式微小 気泡発生器（M2-LM/SCS，(株) ナノプラネット）を 用いた。発生器は, 外付けのポンプにより器内に旋回 水流を生成し，その旋回水流中心部に生じる圧力低下 により外部空気を自然吸引する。発生器内部に吸引さ れた空気は, 空気瀜柱を形成し,この気柱が, 発生器 出口部で旋回水流の速度変化に伴うせん断力作用を受 けて微細化され，微小空気泡が生成される。本装置の 経験的な最適作動条件は, ポンプ吐出量 $17 \mathrm{~L} / \mathrm{min}$, 空 気供給量 $1 \mathrm{~L} / \mathrm{min}$ である。

図 I (a), (b) に, 発生装置の構成と濃度約 3\% の塩水 （約 $27 \mathrm{~L}$ ）の水槽内で発生した微小気泡の様子をそれ ぞれ示す。微小気泡発生器をマグネットポンプ（MD30RZ，(株) イワキ，最大吐出流量 $17 \mathrm{~L} / \mathrm{min}$ ）に接続 し，空気はレギュレーターを介して供給した。塩水の 場合, 装置起動後約 30 秒で図 1 (b) に示すように水 槽内全体が白濁する，装置の構成は，水槽内の塩水を ポンプで吸い込み，発生器を通して気泡と共に水槽へ 吐出する循環方式であるため，水槽内のポンプ吸入口 付近に浮避する気泡は，再びポンプに吸い込まれる。 したがって, 発生器に供給される正確な空気量は明ら かでない.また，装置作動中は発生器出口からの水流 によって水槽内に流れが生じるため, 水槽内のボイド 率分布は均一ではない，なお，水槽内の数箇所から試 料水を採取して計測した結果, 平均ボイド率 $1.1 \%$ を 得た。

微小気泡発生装置で得られた気泡の直径分布は, 気泡 にレーザー光を照射したときの散乱光のドップラー信 号や回折パターン信号を利用した粒径計測装置 (PDA： Phase Doppler Anemometry, DANTEC DYNAMICS) で計測した，結果を図 2 に示す．計測結果は，10 $10 \mathrm{~m}$ (a)

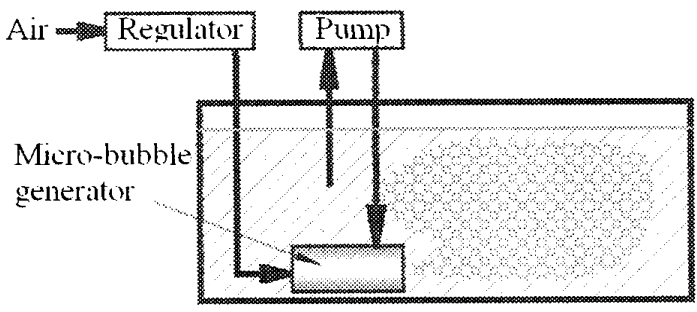

(b)

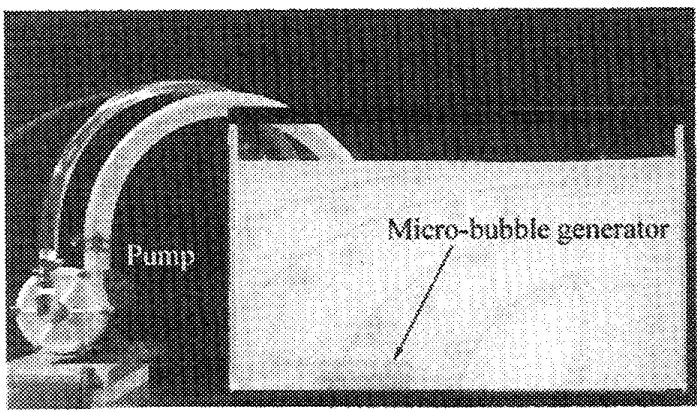

Fig. 1 Schematic diagram of micro-bubble generation system: (a) micro-bubble generator, and (b) bubbly $3 \%$ salt water

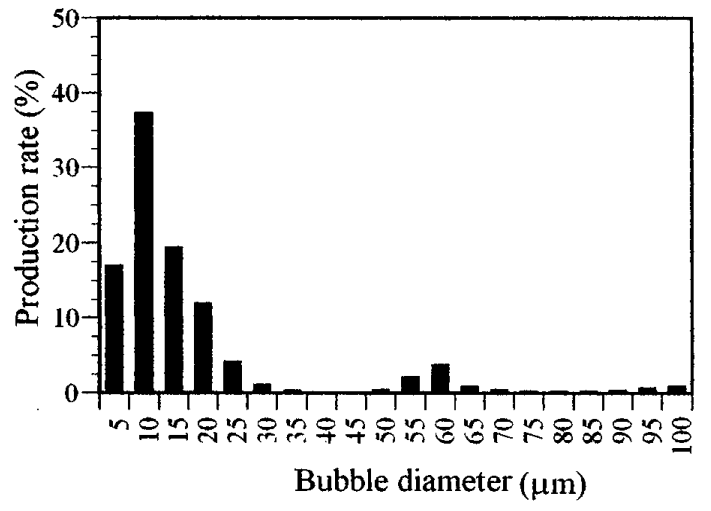

Fig. 2 Bubble size distributions measured by using a PDA system

程度の気泡直径が分布の極值であること, 全体の約 85 $\%$ が直径 $20 \mu \mathrm{m}$ 以下の範囲に分布していることを示 し，ほぼ均一直径の気泡生成が認められた。

\section{2 微小気泡の観察プレパラート2 枚で作製} した $300 \mu \mathrm{m}$ 間隙に微小空気泡を閉じ込め, 正立型顕 微鏡（CX41, OLIMPUS）により気泡直佳の変化を観 察した. 図 3 は, 初期直径 $50 \mu \mathrm{m}$ 気泡の観察結果で あり, 最小 $3 \mu \mathrm{m}$ の気泡直径まで確認できた。初期直 径 $50 \mu \mathrm{m}$ の微小気泡が, 直径 $3 \mu \mathrm{m}$ まで収縮するのに 要した時間は約 650 秒であった．また，このとき気泡 の再膨張現象は確認されなかった。

図 4 は, 微小気泡の直径の時間変化を示している. 縦軸は気泡直径 $(\mu \mathrm{m})$, 横軸は時間 (s) で, 縦軸上の值 は初期直径である。黒丸は計測值, 実線は気泡消滅の 




(a) $0 \mathrm{~s}$

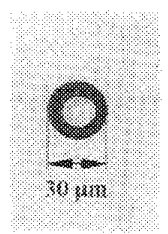

(b) $500 \mathrm{~s}$

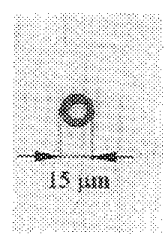

(c) $600 \mathrm{~s}$

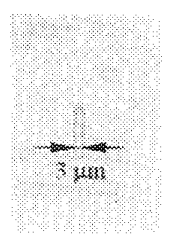

(d) $650 \mathrm{~s}$
Fig. 3 Contraction of a $50 \mu \mathrm{m}$ micro-bubble

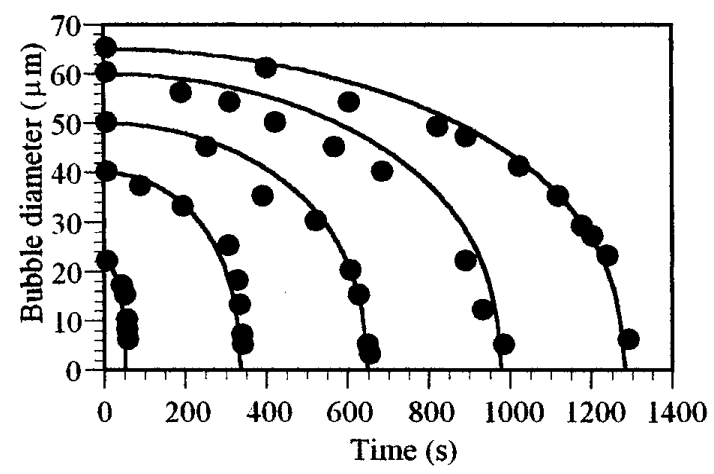

Fig. 4 Microscopic observation of variation of microbubble diameter: filled circles designate measured data, and solid lines solutions of Rayleigh-Plesset equation

実測時間から初期気泡内外圧力差を理論的に見積り， それが常に一定であるとした仮定の下で，圧縮性，粘 性および表面張力を無視した Rayleigh-Plesset の単一 球状気泡方程式から得た解析解である ${ }^{(15)(16)}$. 計測限 界直径に達する時間は，当然のことながら初期直径が 大きいほど長く, 初期直径 $65 \mu \mathrm{m}$ の気泡が限界直径に 達するまでに約 1300 秒を要した。一方, 解析解の曲 線の傾きの変化は，気泡半径の減少に伴う単位体積当 たりの気泡表面積増加に起因した気泡表面速度の増加 を示している，気泡は完全に潰れ，再膨張は生じない． 実験計測結果は, 解析解とほぼ一致しており, 再膨張 現象が生じないことから，熱平衡を保ちながら気液界 面で生じる拡散現象により収縮したと判断される。高 橋ら ${ }^{(13)(14)}$ は，このようにゆっくりとした気泡の収縮 が微小気泡独特の圧壞現象であり，スピントラップ剂 を使用した電子スピン共鳴法（ESR）による実験から， 外压作用なしで消失した微小気泡でもフリーラジカル を発生すると報告している。しかし，微小気泡の自然 圧壊で発生するフリーラジカルの量は不明で, 著者ら が過去に実施した海洋ビブリオ属細菌に対する微小空 気泡のみの細菌不活性化効果の確認実験では, $10 \mathrm{~L} の$ 海水に 12 時間微小気泡を供給した場合, 菌体不活性 効果は高々 $70 \%$ 程度であった ${ }^{(12)}$ 。これは, 微小気泡

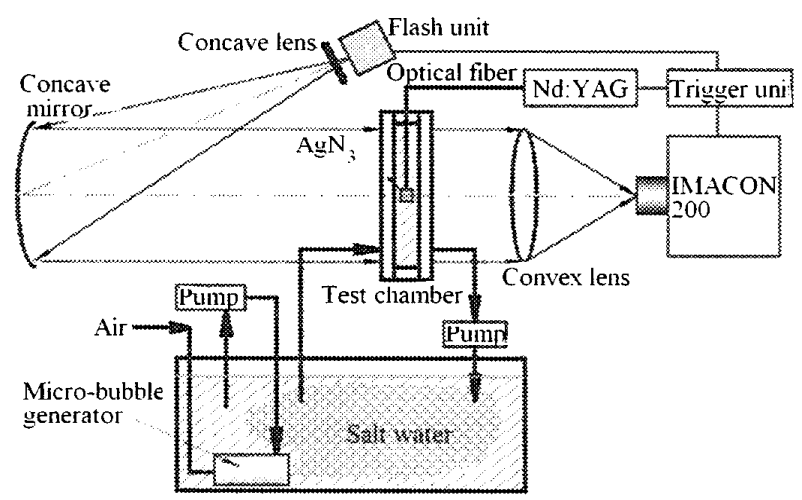

Fig. 5 Experimental setup

Fiber untic probe

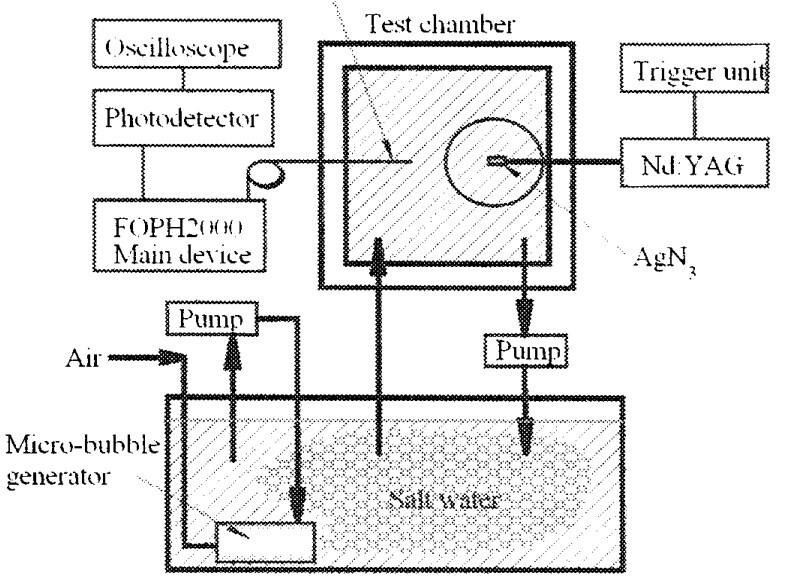

Fig. 6 Pressure measurement by using FOPH 2000

の自然圧壊のみによる殺菌処理効果が極めて低いこと を意味し, 微小気泡で害用可能な不活性化効果を発現 させるためには，外圧負荷等による積極的な気泡再膨 張の促進が必要である.

2.3 可視化と圧力計測 外圧作用で積極的に微 小気泡群の再膨張運動を誘起し, 細菌不活性効果を顕 著に発現できる高压発生を確認するためには，高速度 撮影と高精度の圧力計測が必須である. 微小気泡群の それぞれの気泡運動を誘起するため，アジ化銀 $10 \mathrm{mg}$ を水中爆発させて得られる球状衝撃波を作用させた。 アジ化銀ペレットは, 直径 $0.6 \mathrm{~mm}$ の光ファイバー先端 に接着され，Qスイッチ Nd:YAG レーザー光 $(20 \mathrm{~mJ} /$


アジ化銀の総エネルギの約 $1 / 3$ が球状衝撃波の駆動に 費やされ，衝撃波発生の再現性と時間制御は良好であ $ろ^{(17)}$.

可視化の光学系配置の略図を図 5 に示す，視野幅を 拉大し, 気泡群の存在による光透過性の悪化を避け, 崩壊過程を十分な精度で解像するために, 縦 $110 \mathrm{~mm}$ 
$\times$ 横 $110 \mathrm{~mm} \times$ 奥行き幅 $10 \mathrm{~mm}$ の薄型水槽を使用し た。観測空はアクリル樹脂製である.

試験水槽中心にアジ化銀を配置し，水中衝撃波を発 生させた。水中衝撃波の圧力減衰特性については, 過 去の予備実験で検定されている. 起爆直後, 球状衝撃 波が形成されるが，直ちにアクリル樹脂の空面で反射 し，円筒衝撃波となる．また，微小気泡は，別の水槽 で発生させ，必要に応じて試験水槽へ移送した．水循 環で水槽内に誘起された水流の影響を除去するため, 微小気泡の注入後, 直ちにポンプを停止させ, $10 〜 20$ 秒放置して流れの静止を目視確認した後, アジ化銀 を起爆した，画像の記録には，最高 2 檍コマ/秒の撮 影が可能なイメージコンバーターカメラ IMACON200 （DRS Hadland）を用いた。可視化の視野幅は $56 \mathrm{~mm}$, 拡大視野幅は $10 \mathrm{~mm}$ であった。

圧力計測には, 光ファイバー圧力変換器 (FOPH2000: Fiber Optic Probe Hydrophone, RP acoustics）を使用し た. 圧力変換器の受圧部は, 直径 $0.1 \mathrm{~mm}$ の光ファイ バーである.レーザー光を測定部に導光し，水の密度 変化に伴う屈折率の変化によって変調された光信号を 検知し，それを参照光と比較して屈折率変化を求め, 密度を推定して圧力を求める原理である。ピエゾ素子 の圧力変換器と比較して計測圧力範囲が広く, 電磁的 雑音に影響されないなどの特徵を有する，また，立ち 上がり時間 $3 \mathrm{~ns}$ の高速応答が可能であり, 微小気泡群 の再膨張過程の圧力変動にも追従できる. 機器構成を 図 6 に示す。水槽内に起爆用ファイバーと FOPH2000 ファイバープローブを同軸上に配置し，起爆点からの 距離を変化させて計測を繰り返した。

\section{3. 結果と考察}

3.1 気泡運動の解析 著者らは過去に, $10 \mathrm{mg}$ ア ジ化銀の水中爆発により生成した水中球状衝撃波と直 径 $1.7 \mathrm{~mm}$ の気泡との干渉現象を二重露光ホログラフィ 干渉計法で可視化観測すると共に，その干渉縞分布の 画像解析から衝撃波背後の圧力分布を得ている ${ }^{(18)}$. そ れらの結果は, 衝撃波面が気泡を通過した直後, 気泡 界面で反射澎張波が発生し，気泡周围に波頭が拡大伝 播すると共に，気泡の収縮運動に伴う局所的な圧力上 昇を誘起し，その高圧部を中心とした再膨張衝撃波の 発生と, マイクロジェットの生成を示した. 基本的に, 微小気泡と衝撃波の干渉時においても, 同様の現象が 生じると考えられるが, 気泡群との干渉の場合, 個々 の気泡運動に伴う圧力波が相互に干渉し, 現象はさら に複雑な様相を呈すると推測される。しかしながら， この様な波動現象が関与する複雑な三次元微小気泡運



(a)

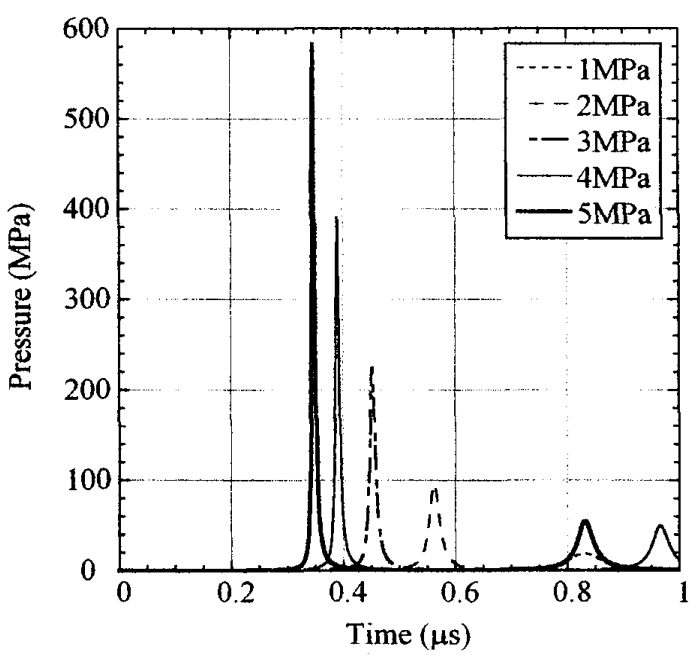

(b)

Fig. 7 Analytical solutions of the bubble dynamic equations at different conditions on ambient pressure: (a) bubble radius vs. time, and (b) pressure inside a bubble vs. time

動を解析することは容易でないことから，まず，簡易 的に一次元の気泡運動方程式による単一微小気泡の解 析を行い，気泡崩壊条件拧よび発生する再膨張衝撃压 の大まかな見積もりを行った.

熱的効果と拡散効果を無視した圧縮性流体中の球状 気泡運動方程式 ${ }^{(19)}(20)$ を解いて, 無限境界液体中に存 在する単一気泡に, 不連続的な圧力上昇を負荷する場 合の気泡の直径と内圧の時間変動を求めた。初期直径 $50 \mu \mathrm{m}$ の気泡に, 1 $5 \mathrm{MPa}$ の圧力を不連続的に負荷 した場合の解析結果を図 7(a), (b) に示す. 先に述べ たように, 実際には単一気泡に平面衝撃波が作用する のに対し, 解析モデルは一次元的であり, 必ずしも現 実と一致しないが，気泡運動を推定するには十分であ ると考えた。図 7(a) より, $1 \mathrm{MPa}$ 以上の不連続的圧力 


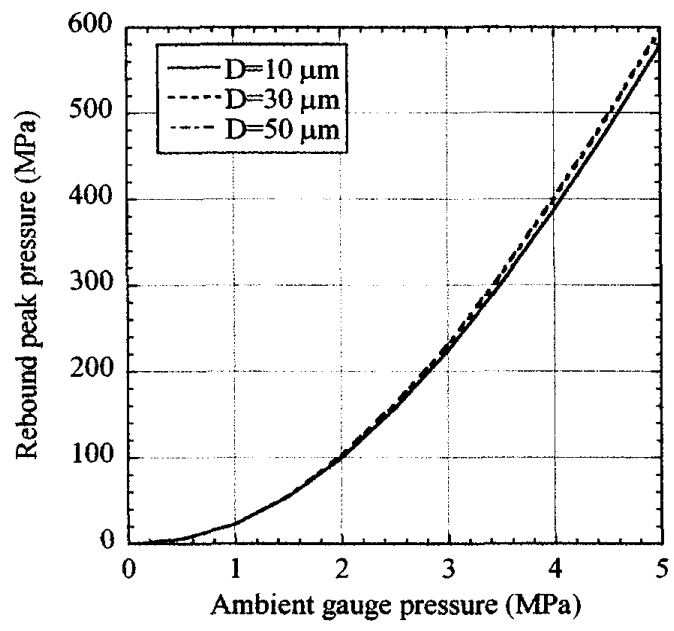

Fig. 8 Rebound peak pressure vs. ambient gauge pressure

負荷に対し, 再膨張は, 圧力作用後 $1 \mu \mathrm{s}$ 以内に生じ, 周期は作用圧力の増加に伴って短くなる。また，一回 目の気泡収縮時の気泡内圧が最も高く, その最大圧は 周囲作用圧力が高いほど増加し，2 $\mathrm{MPa}$ 以上の作用圧 力で数百 $\mathrm{MPa}$ に達する。

図 8 は, 初期直径 $10,30,50 \mu \mathrm{m}$ の気泡の周囲液体 圧と一回目の収縮で得られる極值との関係である. 初 期気泡直径の違いによる極值の顕著な差は認められな い. 先のアルミニウム容器に封入された海洋紐菌の不 活性化実験 ${ }^{(9)}$ (11) で完全不活性化効果が得られた衝撃 压力 $200 \mathrm{MPa}$ に相当する再膨張圧を得るためには, 約 $3 \mathrm{MPa}$ の不連続的過剩圧を負荷しなければならない.

\section{2 微小気泡群と円筒衡躷波の干渉 図 9 に視} 野幅 $56 \mathrm{~mm}$ ，撮影速度 50 万コマ/秒（コマ間隔 $2 \mu \mathrm{s}$ ）, 露光時間 $50 \mathrm{~ns}$ で撮影した画像を示す。気泡群の光吸 収で全体的に画像が暗く，また，直接画像から確認で きる気泡直径は $600 \sim 800 \mu \mathrm{m}$ であった．起爆により発 生する球状衝撃波は, 㝕面で反射して円筒衝撃波 (CS) に移行する。図 9 から, 爆発生成気体, 円筒衝撃波面 およびアクリル樹脂空材中の弾性応力波 (ES) の影を 確認することができる. 各波面の到達位置から見積も られる伝播速度は, 円筒衝撃波か約 $1500 \mathrm{~m} / \mathrm{s}$, 空材料 中応力波が約 $2100 \mathrm{~m} / \mathrm{s}$ であった。爆点から約 $12 \mathrm{~mm}$ 右の位置に確認される直径約 $700 \mu \mathrm{m}$ の気泡 (B) に注 目すると, 衝撃波通過直後に収縮を開始し, 図 9 (f), (g) で, 再膨張衝撃波 (RS) を発生する様子が認められ た.しかし, 図 9 から直径 $100 \mu \mathrm{m}$ 以下の微小気泡は 判別し難いので, 微小気泡の再膨張運動は, 画像診断 できなかった。

図 10 に抎大視野での撮影結果を示す。撮影速度は
100 万コマ/秒（コマ間隔 $1 \mu \mathrm{s}$ ），露光時間は $50 \mathrm{~ns}$ である. 図 10(b)〜 (i) には, 左から右に伝播する水中 衝撃波面が認められ, 衝撃波の右側に, 粒子状の影々 して多数の微小気泡が認められる. 図 10(d), (e)では, これらの影が衝撃波面通過直後に消滅し, 同時にその 領域において屈折率変化を示す明るい採らぎが認めら れる。図 10(f) 以降では, 気泡再膨張のため, 画像は 左から暗くなる. また, 図 10(j)〜(l)では, 気泡の影 が㹡大してより明確になる。これらの可視化結果は, 微小気泡群が水中衝撃波通過直後に収縮を開始し, 最 小体積に達した後, 膨張に転じる一連の過程を示して いる. 本可視化結果から, 気泡が衝撃波作用を受けた 後に再胿張に到る時間は $1 \mu \mathrm{s}$ 以下の短い時間である と見なせる. また, 衝撃波照射で気泡は連鎖反応的に 崩壊するため, 再膨張衝撃波の発生とそれらの相互干 渉により複雑さを増すが, 衝撃波の運動に支配された コヒーレントな反応が生じていると推定できる。これ らを定量的に明らかにするためには，さらなる昖大撮 影と高速画像記録が必要である.

\section{$3 \cdot 3$ 再歔張圧力の計測 図 11 にFOPH2000によ} り起爆点から $20 \mathrm{~mm}$ の位置で得られた円筒衝撃波の 圧力変動を示す。図 11(a)は, 微小気泡なしの結果で ある. 水中衝撃波の圧力変動は明確に判断でき，最大 過剩圧は約 $50 \mathrm{MPa}$ である. 円筒衝撃波背後の圧力値 は，測定部空面での反射の影響により，自由空間を伝 播する場合より高く，圧力減少は緩やかになる。一方， 入射衝撃波直前には, 約 $5 \mathrm{MPa}$ の圧力変動が $200 \mathrm{~ns}$ 間程度認められ，アクリル空中を先行伝播する応力波 により水中に生じた斜め衝撃波の影響が現れている.

図 11(b)は，微小気泡を注入した場合の結果で, 圧 力波形は，気泡なしとは全く異なる。まず，先行斜め 衝撃波による 20〜30 MPa の圧力変動が生じ，その約 $1 \mu \mathrm{s}$ 後に，入射衝撃波と引続く反射波の到達による 約 $60 \mathrm{MPa}$ と $100 \mathrm{MPa}$ の過剩任が発生したと考えられ る.さらに約 $4 \mu \mathrm{s}$ 後, 压力は $200 \mathrm{MPa}$ に上昇し, 約 $150 \mathrm{MPa}$ の值を中心とした振動が数十マイクロ秒間に わたり持続する。図 11(a) と比較して, 発生圧力值は 著しく高く, 微小気泡群の再膨張衝撃波による過剩圧 が原因であると判断できる。また，波形には $200 \mathrm{MPa}$ を超える極大值が周期的に現れる傾向が認められる.

図 11(c)に，周波数解析の結果を示す，縦軸は頻度， 横軸は周波数である．約 $164 \mathrm{kHz}$ にスペクトルの極值 が現れている. 水中衝撃波の伝播速度を $1500 \mathrm{~m} / \mathrm{s}$ と仮 定すると, 測定部幅 $10 \mathrm{~mm}$ の距離を衝撃波が繰り返し 反射する周期は， $150 \mathrm{kHz}$ となり，解析結果の值とほ ぼ一致する．また，微小気泡の再膨張応答時間はナノ 


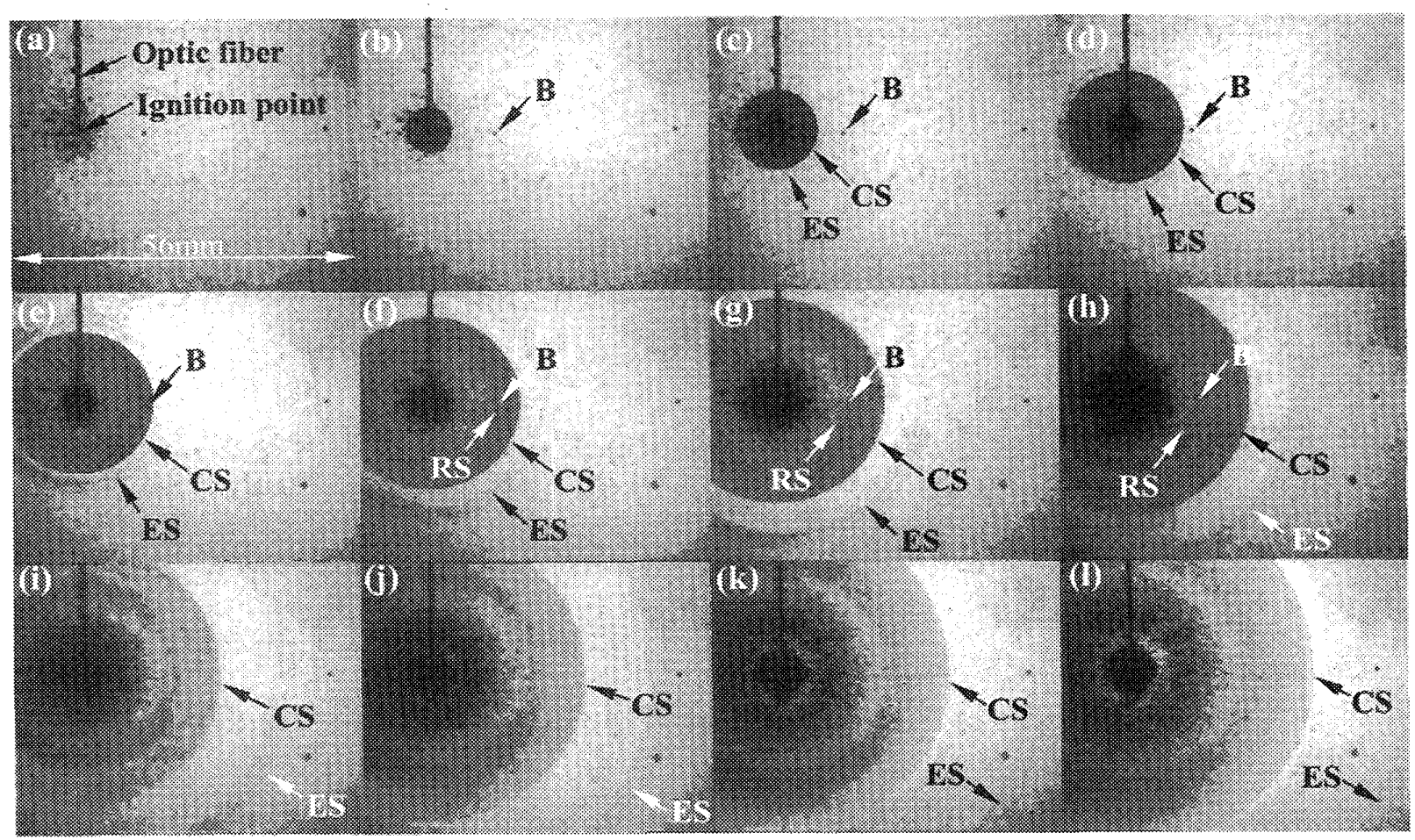

Fig. 9 Micro-explosion of $10 \mathrm{mg} \mathrm{AgN}_{3}$ in the bubbly test chamber. A $700 \mu \mathrm{m}$ diameter bubble $\mathrm{B}$, a cylindrical shock wave CS, elastic stress waves in PMMA windows ES, and a rebound shock wave RS are observed.

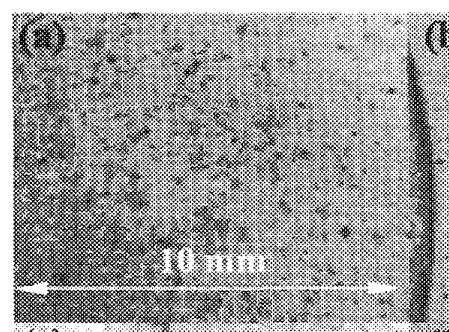

(e)

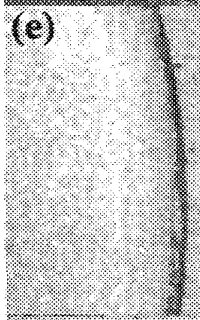

(ii)

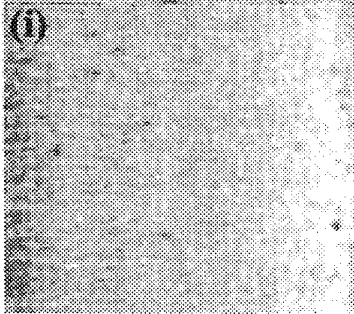

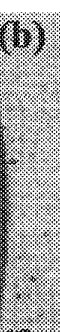

$($ (i)

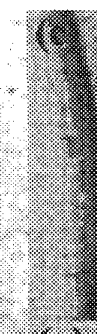

(g)
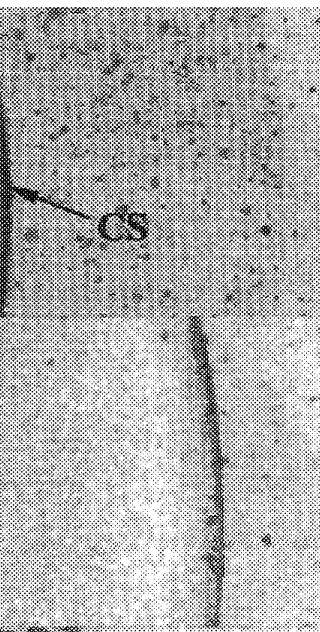

(k)

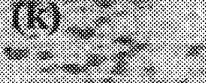

(.). 1.0

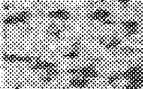

2 -3xs

(d)

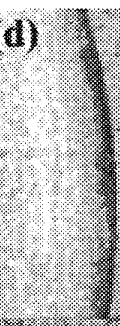

(1):

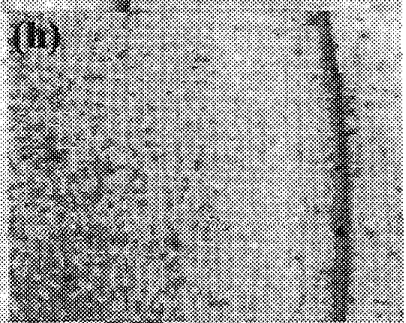

(1)

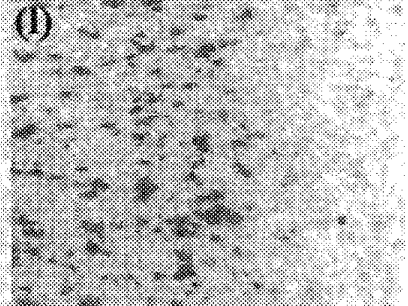

Fig. 10 Close-up visualization of interaction between micro-bubbles and a cylindrical shock wave

秒オーダーであることから，衝撃波作用で気泡は直ち に崩壊して再膨張衝撃波を発生し, それが同位相で測
定部を繰り返し伝播した結果として，高周波数の極值 が多数現れたと考えられる。ささらに，気泡群は，一回 


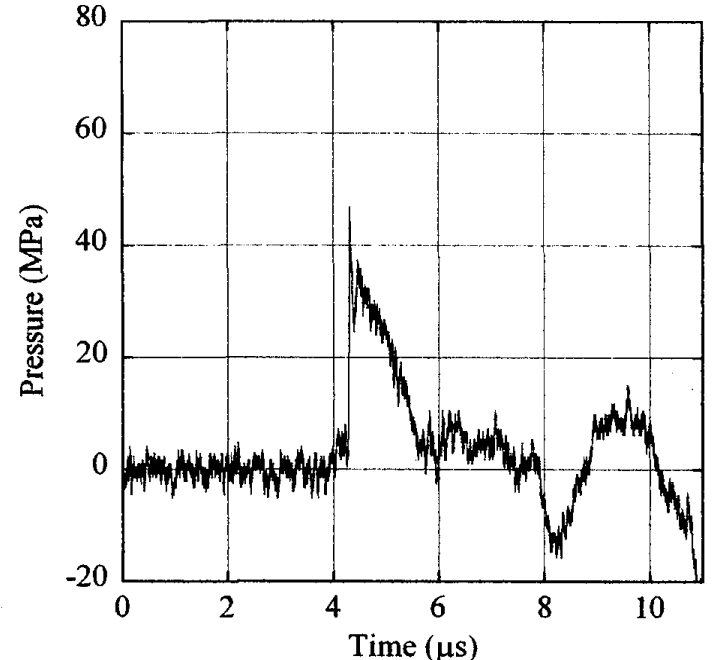

(a)



(b)

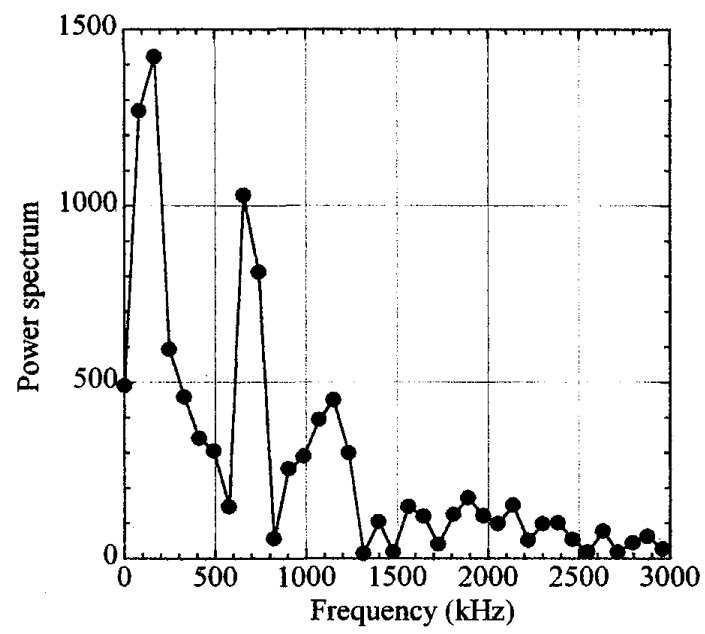

Fig. 11 Measured pressure with FOPH2000 at the distance of $20 \mathrm{~mm}$ from the ignition point: (a) over-pressure in water, (b) with the presence of micro-bubbles, and (c) FFT diagram of (b)

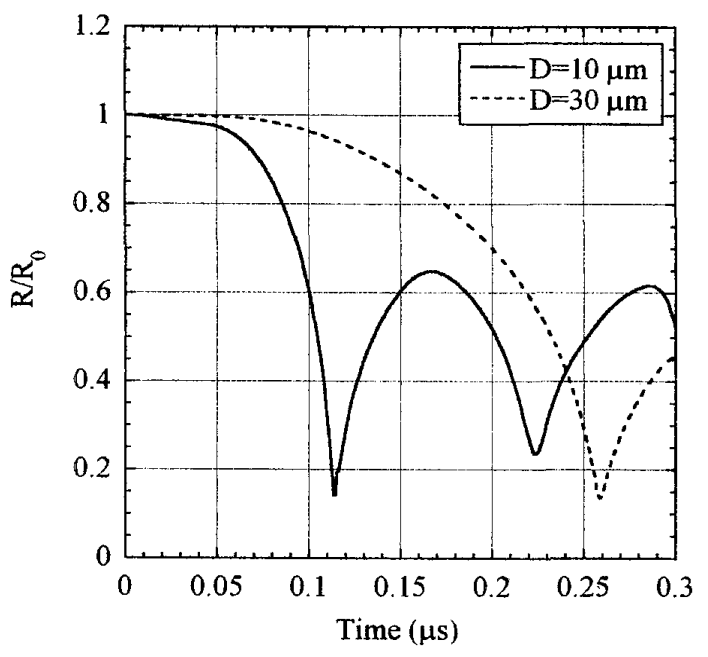

(a)

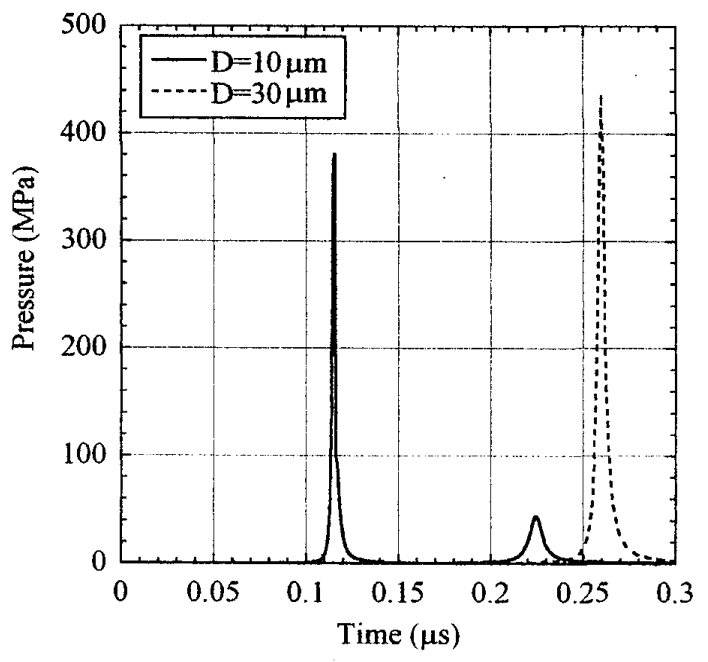

Fig. 12 Analytical solution of bubble motion calculated using pressure data measured with FOPH2000: (a) bubble radius vs. time, and (b) pressure inside bubble vs. time

の崩壊で完全に消滅することなく, 繰り返し励起され て完全に消滅するまで応答を持続したと考えられる。

以上の知見は，再膨張衝撃波の効果を利用する殺菌 装置の設計指針として，気泡群を広い空間に分布させ て外圧負荷するよりも，狭い空間に分布させて外圧負 荷する方が, 比較的長い時間, 高圧を繰り返し発現で きることを示唆する。

初期直径 10，30 $\mathrm{m}$ の単一気泡に，図 11(a)の過剩 压を作用させた場合の気泡運動方程式の解析結果を図 12 に示す．横軸は，円筒衝撃波の圧力上昇の瞬間を原 点とした時間である，最初の再䏽張には，直径 $10 \mu \mathrm{m}$ の気泡で約 $100 \mathrm{~ns}, 30 \mu \mathrm{m}$ の気泡で約 $250 \mathrm{~ns}$ を要し, 再膨張圧は，共に約 $400 \mathrm{MPa}$ である．以上の解析結果 
は, 微小気泡の最初の再膨張が，外圧負荷後数百ナ， 秒の短い時間内に生じ，最大数百 MPa の過剩圧が発 生することを示し，得られた実験事実とほぼ一致した。

\section{4. おわり に}

微小空気泡の再膨張圧を船舶バラスト水処理の一方 法として応用できれば，海洋環境破壊の危惧の無い， 安心・安全な処理技術に結びっく。しかし，その実現 には，微小気泡群を瞬間的に崩壊させて再膨張現象を 誘起し，高圧を発生する機序を詳細に解明し，その制 御法を確立することが重要である。

本研究は, 光学可視化と高速撮影法および微小空間 の圧力変動を高い時間分解能で計測することにより， 限局された狭空間の気泡群に衝撃波圧力作用を与えた 結果, 気泡なしの場合で得られる入射衝撃波過剩压の 数倍に相当する $200 \mathrm{MPa}$ を超える再膨張衝撃圧を数十 マイクロ秒の比較的長い時間, 繰り返して発生できる ことを示した。これらは, 微小気泡を利用する殺菌技 術の開発において重要な知見となる. 今後, 気泡群の 再膨張衝撃圧を援用した海洋菌体不活性効果の確認, および, 装置諸元の最適化を目指して, 気泡封入の最 適ボイド率あるいは最適管直径, 微小気泡運動を誘起 するための実用設計に附え得る水中衝撃波の発生方法 等について詳細な検討が必要である.

\section{謝 辞}

微小気泡の粒子直径計測において, 神户大学海事科学 研究科の藤田浩嗣教授のご協力を得た. また, 本研究の 一部は, 文部科学省中核研究拠点形成計画 12COE2003 の助成を得て実施された。ここに附記し，謝意を表 する。

\section{文献}

(1) Fukuyo, Y., Harmful Transfer of Organisms by Ballast Water, Science of Ship and the Sea, Vol. 7, (2004), pp.3033.

(2) Kikuchi, T., What is the Issue of Ship's Ballast Water?, Sea and Safety(in Japanese), No.67, (2001), pp.2-9.

(3) Ruiz, G. M., Rawlings, T. K., Dobbs, F. C., Drake, L. A., Mullady, T., Huq, A., Colwell, R. R., Global Spread of Microorganisms by Ships, Nature, Vol. 408, (2000), pp.49-50.

(4) International Maritime Organization. "International Convention for the Control and Management of Ships' Ballast Water and Sediments adopted in 2004". Ballast water management. (online), available from $<$ http://www.imo.org/home.asp $>$, (accessed 2008-4-1).

(5) Kikuchi, T., Yoshida, K., Kino, S., Fukuyo, Y., Progress Report on the 'Special Pipe System' as a
Potential Mechanical Treatment for Ballast Water, 2nd International Ballast Water Treatment $R \& D$ Symposium, IMO London, (2003), pp.19-25.

(6) Saho, N., Isogami, H., Mizumori, T., Nishijima, N., Superconduction magnetic separator for ballast-water treatment, 2nd International Ballast Water Treatment $R \& D$ Symposium, IMO London, (2003), pp.125-134.

(7) Abe, A., Mimura, H., Ikeda, T., Katakura, R., Shock Compression of Marine Bacterial Cells Enclosed in Aluminum Container, Journal of the JIME, Vol.40, No. 2, (2005), pp.110-115.

(8) Abe, A., Kawasaki, H., Study on Shock Wave Propagation under Saltwater Sealed in Aluminum Containers, Transactions of the Japan Society of Mechanical Engineers, Series B, Vol.72, No.722, (2006), pp.2418-2424.

(9) Abe, A., Mimura, H., Ishida, H., Yoshida, K., The effect of shock pressures on the inactivation of a marine Vibrio sp., Shock Waves, Vol.17, No.1-2, (2007), pp.143-151.

(10) Mimura, H., Abe, A., Yoshida, K., Ishida, H., Changes in the Number of Colony-Forming Marine Vibrio sp. Cells After Exposure to Shock Pressures in the Presence of Sodium Ascorbate, Bull. Soc. Sea Water Sci., Jpn, Vol.61, No.2, (2007), pp.132-133.

(11) Mimura, H., Abe, A., Ishida, H., Changes of marine bacterial populations in a ship's ballast water and sediment, and application of shock pressures to complete killing of Vibrio sp. cells isolated from ballast water, Environmental Microbiology Research Trends edited by G. V. Kurladze, (2007), pp.191-212.

(12) Abe, A., Kanai, H., Mimura, H., Nishio, S., Ishida, H., Study on application of shock waves generated by micro bubbles to the treatment of ships' ballast water, Proc. 26th International Symposium on Shock Waves, (2007), A4890.

(13) Takahashi, M., Chiba, K., Li, P., Free-Radical Generation from Collapsing Microbubbles in the Absence of a Dynamic Stimulus, J. Phys. Chem. B, Vol.111, No.6, (2007), pp.1343-1347.

(14) Takahashi, M., Chiba, K., Li, P., Formation of Hydroxyl Radicals by Collapsing Ozone Microbubbles under Strongly Acidic Conditions, J. Phys. Chem. B, Vol.111, No.39, (2007), pp.11443-11446.

(15) Rayleigh, Lord., On the pressure developed in a liquid during the collapse of a spherical cavity, Phil. Mag., Vol.34, (1917), pp.94-98.

(16) Plesset, M. S., The Dynamics of Cavitation Bubbles, $J$. Appl. Mech., Vol.16, (1949), pp.277-282.

(17) Takayama, K., Holographic interferometric study of shock wave propagation in two-phase media, Proc. 16th Int. Symp. Shock Tubes Waves, (1991), pp.51-62.

(18) Abe, A., Shock wave refraction and flow from an openended shock tube (in Japanese), Doctoral thesis, Graduate School of Tohoku University, (1991), pp.42-44.

(19) Tomita, Y., Shima, A., Mechanisms of impulsive pressure generation and damage pit formation by bubble collapse, J. Fluid Mech., Vol.169, (1986), pp.535-564.

(20) Shima, A., Studies on bubble dynamics, Shock Waves, Vol.7, (1997), pp.33-42. 